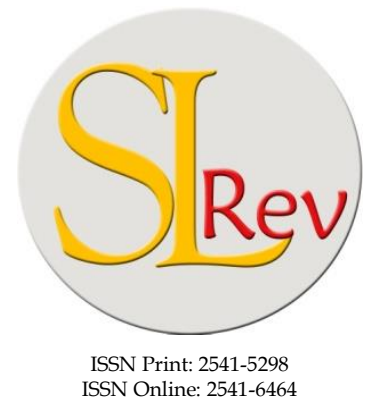

\section{Implementation of the UNCLOS 1982 in Utilization of Highly Migratory Species By Indonesia}

Editorial Office: Faculty of Law, Sriwijaya UniversityJalan Srijaya Negara, Palembang, South Sumatra 30139, Indonesia.

Phone: +62711-580063Fax: +62711-581179

E-mail: sriwijayalawreview@unsri.ac.id| sriwijayalawreview@gmail.com

Website: http://journal.fh.unsri.ac.id/index.php/sriwijayalawreview

Usmawadi $^{\mathrm{a}}$

a Faculty of Law, Universitas Sriwijaya, Indonesia. E-mail: wadiamir@yahoo.com.sg

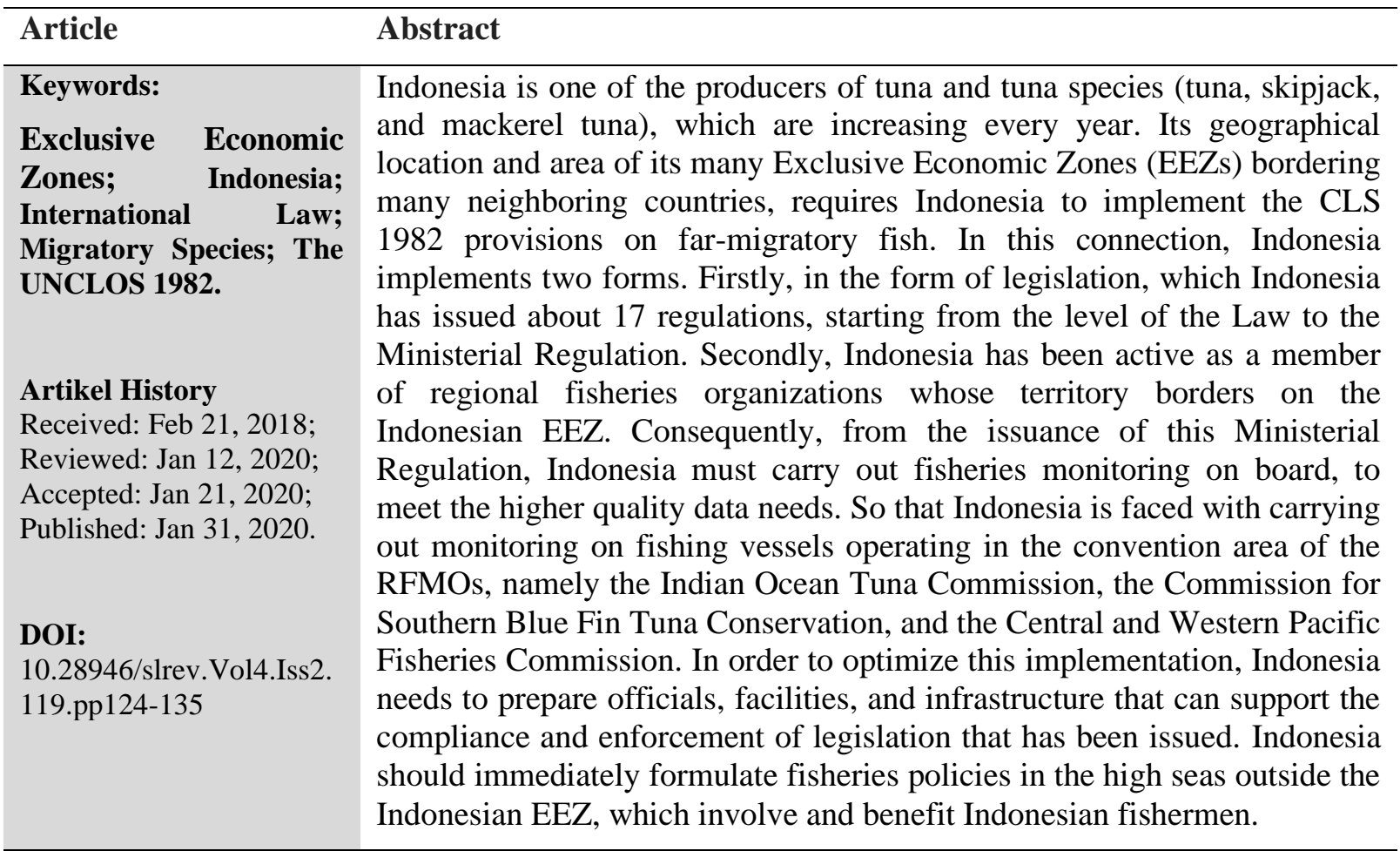

(C)2020; This article is an Open Access Research distributed under the term of the Creative Commons Attribution License (https://Creativecommons.org/licences/by/4.0), which permits unrestricted use, distribution, and reproduction in any medium, provided the original works is properly cited.

\title{
INTRODUCTION
}

Indonesia is an archipelago consisting of around 17,508 islands with an area of 5,193,250 square kilometers, and after ratifying the United Nations Convention on the Law of the Sea 1982 (CLS 1982) to 8,193,250 square kilometers, consisting of 2,027,087 square kilometers of land and 6,166,163 square kilometers of territorial waters. Indonesia's territorial waters include 0.3 million square kilometers of the territorial sea, 2.8 million square kilometers of 
archipelago waters, and 2.7 million square kilometers of Exclusive Economic Zones (EEZs). ${ }^{1}$ As a follow-up to the CLS 1982 ratification by the Law Number 17 of 1985, Indonesia needs to implement it, including the utilization of fisheries resources, especially distant migratory fish. CLS 1982 mandates that coastal countries and other countries whose citizens use far migratory species in an area must cooperate directly or through international organizations (Article 64).

Far-migratory fish are fish with very high cruising. Among migratory fish according to UNCLOS 1982, are sail-fishes $112 \mathrm{~km} / \mathrm{h}$, marlins can reach $112 \mathrm{~km} / \mathrm{h}$, bluefin tuna $70 \mathrm{~km} / \mathrm{h}$, yellowfin tuna $74 \mathrm{~km} / \mathrm{h}$, blue shark $67 \mathrm{~km} / \mathrm{h}$, swordfish $64 \mathrm{~km} / \mathrm{h}$, tiger shark $56 \mathrm{~km} / \mathrm{h} .{ }^{2}$ Tuna is the largest type of fish that falls into the category of far-migratory fish, according to Appendix I UNCLOS 1982 there are nine types of tuna from seventeen types of far-migrated fish. Tuna usually live in clusters and always do activities at speeds of $27 \mathrm{~km} / \mathrm{h}$ up to $75 \mathrm{~km} / \mathrm{h}$, both local and long-distance movements. ${ }^{3}$ With such a rapid movement, the types of far-migratory fish can be said to be unfamiliar with the boundaries of the territorial waters of a country or migrate across the jurisdictional borders of a country. Such conditions can cause legal problems. The related countries with this type of fish feel entitled to catch the fish. For example, the countries where the fish lay the eggs, grow up, and choose the final destination to settle (live) feel entitled to the existing fish. As a result, there can be a violation of state sovereignty by another country. So, its utilization must involve all stakeholders and a group of governments at the national and international levels.

Indonesia is one of the producers of tuna and tuna species (tuna, skipjack, and mackerel tuna), which are increasing every year. Specifically, tuna and cob from the first quarter to the third quarter of 2015 experienced an average growth of $27.22 \%$ and $19.94 \%$, with an average production of 79 tons (tuna) and 241 tons (cob). The most significant growth for tuna is albacore, bluefin tuna, and bigeye tuna. ${ }^{4}$ Previously, in 2014 each grew $2.76 \%$ (tuna), $14.31 \%$ (skipjack) and $3.26 \%$ (tuna) compared to 2013. The total tuna production in 2013 was 305,435 tons to 313,873 tons in 2014 skipjack 2013 was 481,014 tons in 2014 to 496,682 tons and cob from 451,048 tons in 2013 to 515,571 tons in $2014^{5}$.

In addition, the Indonesian EEZ is bordered by many neighboring countries and located between the Indian Ocean and the Pacific. As a migratory fish producer and the geographical conditions of Indonesia between the two oceans, it certainly requires the implementation of the CLS 1982 provisions on far migratory fish, both in the form of legislation and in the form of cooperation between countries. So the main problems in this paper are: How the Indonesian

1 Kasijan Romimohtarto, "Pengelolaan Pemanfaatan Kekayaan Hayati Dan Nabati Di Perairan Indonesia," Seminar Hukum Nasional Kelima Tahun 1990 (Jakarta, 1991).

2 Wang Yanfang, "Top 10 Fastest Fish in the World," accessed April 27, 2017, http://www.china.org.cn/top10/2010-12/28/content_21633018_5.htm.

3 A. Dwiponggo, "Pemanfaatan Dan Pengelolaan Optimal Perikanan Laut Dalam Pembangunan Jangka Panjang (PJP) Tahap II," in Prosiding Forum-II Perikanan (Jakarta: Balitbang Pertanian Pusat Penelitian dan Pengembangan Perikanan kerjasama dengan USAID/FRDF, 1991), 114.

4 Krisna Fery Rahmantya, Anggie Destiti Asianto, and Dadang Wibowo, Analisis Data Pokok Kelautan Dan Perikanan 2015, ed. Rennisca Ray Damanti and Mareta Nirmalanti (Jakarta: Pusat Data, Statistik dan Informasi Kementerian Kelautan dan Perikanan, 2015).

5 Rahmantya, Asianto, and Wibowo. 
law regulates the conservation and management of migratory fish? Moreover, what is an international cooperation with Indonesia?

\section{RESEARCH METHOD}

This article is included as normative legal research with statute approach. Data analysis of this research is deductive-qualitative. Statute approach is applied to examine international legal provisions which discuss international law of the sea, especially the United Nations Convention on the Law of the Sea 1982. In addition, some more specific regulations governing Highly Migratory Species will also be the focus of this study, such as FAO Compliance Agreement 1993, United Nations Implementing Agreement 1995 and other related international agreements.

\section{ANALYSIS AND DISCUSSION}

\section{International Arrangements of Highly Migratory Species}

There are several international legal provisions which specifically address the issue of Highly Migratory Species. The rules are international-scale and some are regional agreements between countries in certain regions or sub-regions. Some of the rules of international law include:

\section{a. United Nations Convention on the Law of the Sea 1982}

According to Articles 61-67 UNCLOS 1982, the regulation regarding far migratory fish contains in Chapter V: Exclusive Economic Zone. In this chapter, Article 61 clearly mandates cooperation between coastal countries and international organizations to carry out fisheries conservation and management actions based on the best scientific evidence. ${ }^{6}$

When the supply of the same type fish is found within two or more coastal countries both in the EEZ and the outside, these countries must coordinate through regional organizations to develop an agreement for the actions needed, such as conservation of the supplies (Article 63). Particularly for far migratory fish, the coastal countries and other countries whose citizens use fish species that far migrate in the region must cooperate directly or through international organizations (Article 64 UNCLOS 1982).

The High Sea Regime is regulated in Chapter VII (Articles 86-120). Management and conservation of resources on the high seas can be done unilaterally or in cooperation between countries (Article 117). The countries must regulate management and conservation, and if possible, by establishing regional fisheries management organizations in various regions that have their own rules for managing fisheries activities (Article 118).

\section{b. FAO Compliance Agreement 1993}

This agreement was developed based on obligations in CLS 1982 for countries whose ships caught fish on the high seas. The application of the Compliance Agreement is intended for all vessels used or intended to catch fish on the high seas, except that a party may free fishing vessels less than 24 meters in length, provided that they will not damage the purpose and intent of the agreement. This release does not reduce the principal obligation of the agreement, namely, to ensure that the vessel concerned does not reduce

6 The United Nations, "The United Nations Convention on the Law of the Sea" (1982). 
the effectiveness of international conservation and management actions as stated in the Article 2 this agreement. ${ }^{7}$

It is determined that the flag state is responsible for taking steps that are deemed necessary to ensure that fishing vessels flying their flags are not involved in any activities that reduce the effectiveness of conservation and international management. ${ }^{8}$ Each party may not allow fishing vessels to fly their flags to catch fish on the high seas unless they have been authorized by the competent authority or the authority of that party. Fishing vessels that are given permission must catch under the terms of the permit. ${ }^{9}$

\section{c. United Nations Implementing Agreement 1995 (UNIA)}

This agreement contains general principles, state obligations ${ }^{10}$ in the context of conservation and management of limited migratory fish stocks and remote migration. In this agreement Article 5 state that the state parties must:

"a) take actions to ensure the long-term sustainability of fish stocks that are limited and far-flung with energy and optimal use; b) guarantee that the action is based on the best scientific evidence available and designed to maintain or restore fish stocks; c) apply a precautionary approach; d) measuring the impact of fishing, other human activities, and environmental factors on target stocks and species included in the same ecosystem; e) take conservation and management actions for species in the same ecosystem or unite/relate to or depend on the target stock; f) minimize pollution, garbage, useless catches, abandoned fishing gear, catches of non-target species, both fish and non-fish species, and impacts on species; g) protect biodiversity in the marine environment; h) take actions to prevent and/or reduce overfishing and overfishing fishing; i) pay attention to the interests of coastal fishers and subsistence; j) collect and provide complete and accurate data on fisheries activities, among others, the position of ships, catches of target and non-target species and fishing businesses, as well as information from national and international research programs; k) advance and carry out scientific research and develop appropriate technology; and 1) implement and implement conservation and management actions through monitoring, supervision, and control."11

Apart from the provisions above, it is also regulated in Article 7 of this agreement defines that conservation and management actions on the high seas and in areas under national jurisdiction must be adjusted and made within a reasonable period. ${ }^{12}$

Countries that are members of sub-regional or regional fisheries organizations or arrangements, and collaborate in the application of conservation and management provisions, which have access rights to utilize species that have limited migration and far migratory on the high seas. ${ }^{13}$ In implementing its access rights, countries that have been members of regional fisheries organizations are required to approve "Total Allowable Catch/TAC" and "Levels of Fishing Effort," and have prepared mechanisms for effective monitoring, control, and surveillance and MCS activities. ${ }^{14}$

In the formation of sub-regional or regional management organizations or settings, countries must agree, among other things, on the supply, the area of application, the work relations with existing organizations, and the mechanism to obtain scientific direction and

\footnotetext{
"FAO Compliance Agreement 1993" (n.d.).

FAO Compliance Agreement 1993.

FAO Compliance Agreement 1993.

10 Nurhidayatuloh and Febrian, "ASEAN and European Human Rights Mechanisms, What Should Be Improved?," Padjadjaran Journal of Law 6, no. 1 (2019): 151-67.

11 "United Nations Implementing Agreement 1995 (UNIA)" (n.d.).

12 United Nations Implementing Agreement 1995 (UNIA).

13 United Nations Implementing Agreement 1995 (UNIA).

14 United Nations Implementing Agreement 1995 (UNIA).
} 
changes in the status of the preparation. Non-member countries are bound by the obligation to cooperate in conservation efforts and management of fish species that migrate on a limited scale and far migratory under CLS 1982 provisions. ${ }^{15}$

The flag state must act so that the ship that raises its flag, which catches fish in the high seas, adheres to conservation and management actions. The state also guarantees compliance and law enforcement by its vessels. Law investigations and prosecutions are carried out quickly. Sanctions are applied hard enough so that they are effective in guaranteeing compliance and preventing violations. In law enforcement, cooperation between countries is required both internationally, sub-regional and regional. ${ }^{16}$

Flag states can take action against their vessels who commit violations, it is also possible for other countries but must be proportional to the type of violation, including the vessels that catch fish on the high seas without nationality. The port state may take actions under international law, to advance the effectiveness of sub-regional, regional and global conservation and management actions without discrimination. ${ }^{17}$

\section{1) FAO Code Conduct for Responsible Fisheries (CCRF) 1995}

The CCRF must be interpreted under CLS 1982, the Fish Stocks Agreement, and other applicable international laws. Four international action plans (IPOAs) have been developed under CCRF, namely IPOA-Seabirds, IPOA-Sharks, IPOA-Capacity, and IPOA-IUU. CCRF requires the state and users of aquatic biological resources to preserve water ecosystems, as well as the obligation to do so responsibly so as to ensure the conservation and effective management of water resources life. ${ }^{18}$

State management actions and RFMOs are to regulate the catch of non-target species, both fish and non-fish, and the impacts that are related or dependent on species are minimized through agreed actions, including if possible, the development and use of selective, environmentally friendly and cause a little loss. If fish stocks are exploited by two or more countries, the country concerned must cooperate to ensure conservation and effective resource management through the establishment of bilateral, sub-regional or regional fisheries organizations or arrangements. The flag state must ensure that its fishing vessels catch fish on the high seas unless the vessel has been given a registration certificate and has been authorized by the competent authority. ${ }^{19}$

\section{2) FAO International Plan of Action for the Management of Fishing Capacity}

FAO International Plan of Action for the Management of Fishing Capacity (IPOA) is a follow-up of the obligations of countries in CCRF. The arrangements for strengthening the existence of RFMOs in IPO for the Management of Fishing Capacity are clearly illustrated in the four main strategies to achieve the objectives of the IPOA, namely strengthening regional fisheries organizations and related mechanisms to improve fisheries capacity management at regional and global levels. It is then reinforced with the obligation to

\footnotetext{
United Nations Implementing Agreement 1995 (UNIA).

United Nations Implementing Agreement 1995 (UNIA).

United Nations Implementing Agreement 1995 (UNIA).

"FAO Code Conduct for Responsible Fisheries (CCRF) 1995" (n.d.).

FAO Code Conduct for Responsible Fisheries (CCRF) 1995.
} 
collaborate through RFMOs in order to ensure effective management of fishing capacity. IPOA for the Management of Fishing Capacity also encouraged countries to become members of the RFMOs and agreed to implement management and conservation measures and arrangements for their vessels regulated by the RFMOs.

\section{3) FAO International Action Plan for Illegal, Unreported, and Unregulated Fishing}

The aim of the IPOA-IUU is to prevent, deter and eradicate IUU Fishing by providing all countries with comprehensive, effective and transparent actions that can be used to act, including through regional fisheries management organizations established in accordance with international law. IPOA-IUU is voluntary and has been elaborated in Article 2 letter d of the FAO Code of Conduct for Responsible Fisheries. ${ }^{20}$

\section{Implementation of CLS 1982 in Legislation.}

As stated that Indonesia ratified the 1982 CLS with Law No. 17 of 1985 . Following up on the 1982 ratification of CLS and the above international provisions, Indonesia has issued many laws and regulations, including:

a. Law Number 5 of 1983 concerning the Indonesian Exclusive Economic Zone;

b. Law Number 6 of 1996 concerning Indonesian Waters;

c. Law Number 31 of 2004 concerning Fisheries, as amended by Act Number 45 of 2009;

d. Law Number 21 of 2009 concerning Ratification of the Agreement for the Implementation of the United Nations Convention on the Law of the Sea of 10 December 1982 Relating to the Conservation and Management of Straddling Fish Stocks and Highly Migratory Fish Stocks/UNIA );

e. Law Number 32 of 2014 concerning Marine Affairs;

f. Government Regulation Number 15 of 1984 concerning the Use of Natural Resources in the Exclusive Economic Zone;

g. Regulation of the Minister of Marine and Fisheries No. PER.01/MEN/2009 concerning Fisheries Management Areas of the Republic of Indonesia;

h. Regulation of the Minister of Marine and Fisheries No. PER.12/ MEN / 2012 concerning Capture Sea Fishing Business;

i. Regulation of the Minister of Marine and Fisheries No. PER.30/MEN/2012 concerning Capture Fisheries in the Fisheries Management Areas of the Republic of Indonesia;

j. Regulation of the Minister of Marine and Fisheries No. PER.08/MEN/2012 concerning the Port of Fisheries;

k. Regulation of the Minister of Marine and Fisheries No. 48/PERMEN-KP/ 2014 concerning Fishing Log Book;

1. Regulation of the Minister of Marine Affairs and Fisheries No. 23/PERMEN-KP/ 2015 concerning the Organization and Work Procedure of the Ministry of Maritime Affairs and Fisheries;

m. Regulation of the Minister of Marine Affairs and Fisheries No. 42/PERMEN-KP/2015 concerning Fishing Vessel Monitoring System;

20 FAO, “About IPOA-IUU,” accessed May 17, 2016, http://www.fao.org/fishery/ipoa-iuu/about/en. 
n. Regulation of the Minister of Marine and Fisheries No. 71/PERMEN-KP/ 2016 concerning Fishing Lines and Placement of Fishing Equipment in Fisheries Management Areas;

o. 2/PERMEN-KP/2015 concerning Prohibition on the Use of Trawls and Seine Nets in the Fisheries Management Areas of the Republic of Indonesia;

Law No. 5 of 1983 concerning EEZ regulates the definition of natural resource conservation, namely all efforts aimed at protecting and conserving natural resources in the Indonesian EEZ. This Law is the first 1982 implementation of UNCLOS conducted by Indonesia.

Then with Law Number 17 of 1985 and Law Number 31 of 2004, it can be said that both are the implementation steps taken by Indonesia relating to the conservation and management of far migratory fish. Law No. 31 of 2004 regulates fisheries issues entirely. Nevertheless, in subsequent developments, this law was amended by Law No. 45 of 2009 concerning Amendment to Law No. 31 of 2004. Law Number 31 of 2004 is considered unable to anticipate technological developments and developments in legal needs in the context of managing and utilizing the potential of fish resources and has not been able to answer problems related to fisheries development so that changes in some substances need, both concerning management aspects, bureaucracy, and legal aspects. Law No. 45 of 2009 leads to partiality to small fishers and small fish farmers, among others, in the aspects of licensing, the obligation to implement provisions concerning fishing vessel monitoring systems, fisheries levies, and the imposition of criminal sanctions. ${ }^{21}$

Since 2005 the Directorate General of Supervision and Control of Marine and Fisheries Resources has been formed (P2SDKP). P2SDKP functions to supervise and control the implementation of the utilization of marine and fisheries resources. P2SDKP has developed the concept of monitoring, control, and surveillance (MCS) system.

The implementation of a ship monitoring system (VMS) is regulated in Law No. 45 of 2009, wherein supporting fish resource management policies, the Minister established a fishing vessel monitoring system. ${ }^{22}$ Every person conducting a business and/or fish management activity must comply with these provisions. It was then followed by the Minister of Maritime Affairs and Fisheries Regulation Number PER.05/MEN/2007 revoked by Ministerial Regulation No.42/PERMEN-KP/2014. It was determined that fishing vessels measuring 30 GT and above must install SPKP transmitters, and must activate the transmitter and can be monitored at the Fisheries Ship Monitoring Center (PPKP). ${ }^{23}$

In addition to carrying out monitoring of fishing vessels, the state also stipulates, controls and regulates the type, number and size of fishing gear, fishing ports, requirements or standards for fishing operations namely Fisheries Business License (SIUP), Fishing License (SIPI), Fish Transport Vessel Permit (SIKPI), and registration of ships, types of fish that may be caught and types of fish that are prohibited from being traded included, and issued to and

21 "Law No. 45 of 2009 Amending Law No. 31 of 2004 Concerning Fishery" (n.d.).

22 Law No. 45 of 2009 Amending Law No. 31 of 2004 concerning Fishery.

23 Law No. 45 of 2009 Amending Law No. 31 of 2004 concerning Fishery. 
from Indonesian territory as well as the establishment of fisheries courts and the imposition of severe sanctions for violators of these provisions. ${ }^{24}$

In 2009 the Ministry of Marine Affairs and Fisheries issued its regulation No. PER.03/MEN/2009 concerning fishing and/or transportation of fish in the high seas. Then it was revoked by the Regulation of the Minister of Marine and Fisheries No.12/MEN/2012 concerning Capture Fisheries Business. This revocation is in the context of active Indonesia in the three Regional Fisheries Management Organizations (RFMOs) around Indonesia, namely WCPFC, CCSBT and IOTC.

\section{Implementation in Regional Cooperation}

CLS 1982 provides mandates to countries to collaborate at sub-regional and regional levels in the field of fisheries management and conservation. Today there are approximately 17 RFMOs, five of which are specifically tuna RFMOs. RFMOs are responsible for managing around 91 percent of the world's marine fisheries. ${ }^{25}$ Indonesia is active in three RFMOs whose territory surrounds Indonesian waters, namely:

\section{a. Indian Ocean Tuna Commission (IOTC)}

The IOTC area is the Indian Ocean (defined for the purposes of the Agreement as FAO statistics areas 51 and 57), and adjacent seas, north of the Antarctic meeting, insofar as it is necessary to cover the ocean for the purpose of conservation and management of migratory fish to or from the Ocean India. In 1999, the Commission extended the western boundary of the IOTC statistical area from $30^{\circ} \mathrm{E}$ to $20^{\circ} \mathrm{E}$, thereby removing gaps between the areas covered by the IOTC and the International Commission for Conservation of Atlantic Tunas (ICCAT). The species managed by IOTC is a type of tuna. Approval for the Formation of the IOTC was concluded based on Article XIV of the FAO Constitution. This agreement was approved by the FAO Council in November 1993 and entered into force on the tenth accession of the Members in March 1996. ${ }^{26}$

Indonesia became the 27th full member of the IOTC on June 20, 2007, through Presidential Regulation No.9 of 2007 concerning Ratification of the Agreement for the Establishment of the Indian Ocean Tuna Commission on March 5, 2007. In 2013 there were 1,256 Indonesian ships registered in IOTC. However, only 610 ships have active Fishing License (SIPI), which consists of nine units of purse seine vessels, 593 longline vessels, and eight other fishing gear. ${ }^{27}$

Since becoming a member of IOTC Indonesia has carried out several activities including: (1) tuna fishery revitalization program, (2) information delivery to the IOTC secretariat about Authorized Vessel and Active Vessel or vessels that are active and officially making tuna fishing, (3) preparation of Ministerial Regulations No PER.03 /

Law No. 45 of 2009 Amending Law No. 31 of 2004 concerning Fishery.

Law No. 45 of 2009 Amending Law No. 31 of 2004 concerning Fishery.

26 "Regional Fishery Bodies Summary Descriptions Indian Ocean Tuna Commission (IOTC)," accessed May 17, 2013, http://www.fao.org/fishery/org/iotc_inst/en.

27 Ana Noviani, "Indonesia Registers 1,256 Fishing Vessels in the IOTC," accessed April 28, 2017, http://industri.bisnis.com/read/ 20131222/99/193752/indonesia- 1,256-boat-fish-di-iotc. 
MEN / 2009 concerning Fishing and/or Transport of Fish in the High Sea, ${ }^{28}$ (4) preparation of the application of fisheries Log Book, (5) program of outer fishing port or outermost fishing port; and (6) together with Australia to form a Regional Plan of Action (RPOA) to Promote Responsible Fishing Practices (including Combating IUU Fishing) in the Region, namely the action plan of two countries to realize responsible fisheries management including eradicating IUU Fishing. ${ }^{29}$

\section{b. Commission for Converging South Blue Fin Tuna (CCSBT)}

On May 10, 1993, Australia, Japan, and New Zealand signed the Convention for Conservation of Southern Bluefin Tuna, which became effective on May 20, 1994, after the three countries formalized. Korea and Indonesia joined the Commission on October 17, 2001, and April 8, 2008. Taiwan conclusively dated August 30, 2002. At the October 2003 meeting, the CCSBT agreed to invite countries with interest in fisheries to participate in their activities as "Non-formal cooperation members." Non- formal Cooperation Members fully participate in "CCSBT" affairs but do not have voting rights. The Philippines, South Africa, and the European Union were officially accepted as Non-Cooperation Members on August 2, 2004, August 24, 2006, and October 13, 2006. ${ }^{30}$

Indonesia became a member of CCSBT through Presidential Regulation No. 109 of 2007 concerning the Ratification of the Convention for the Conservation of Southern Bluefin Tuna on 6 December 2007. The Member States of CCSBT are Australia, New Zealand, South Korea, Japan, the Philippines, Indonesia, and Taiwan. Taiwan included especially in the expanded commission where the membership is not a state, but the organization of the fishing company. Philippines, South Africa, and the European Union as co-operating non-members who are required to agree on the limit on the number of catches. $^{31}$

At the 18th annual meeting, the CCSBT approved a Management Procedure (MP), which was used as a guide to determine the amount of global catch allowed (global SBT total allowable catch / TAC). Based on the agreed MP, the TAC is set at a three-year period. The allowable catch amount (TAC) for the 2014-202 period, namely: 2014 as many as 12,449 tons, 2015 - 2017 is around 14,647 tons and $2018-2020$ to 17,647 tons. $^{32}$

\section{c. Central and Western Pacific Fisheries Commissions (WCPFC)}

WCPFC was established through the Convention and the Conservation and Management of the Highly Western and Central Pacific Ocean Fish Stocks Migratory (WCPF Convention), which came into force on June 19, 2004. Species managed by WCPFC are all stocks of distant migratory fish in convention areas except sauries. The convention aims to ensure through effective, long-term conservation and sustainable use of highly migratory

\footnotetext{
28 "Minister of Maritime Affairs and Fisheries Regulation Number PER.12/MEN/2012 Concerning Capture Fisheries Business in The Sea" (n.d.).

29 "Indonesia Is More Active in Managing Tuna Fisheries in the Indian Ocean," Antara News, n.d.

30 "Non-Formal Cooperation Members," accessed April 18, 2017, http://www.ccsbt.org/site/origins_of_the_ convention.php.

31 Husain Latuconsina, "Fisheries Development Opportunities and Challenges through UN Fish Stock 1995," accessed May 5, 2013, https://id.scribd.com/document/ 22593051/Peluang-Dan-Tantangan-PembangunanPerikanan- Me-lalui-Un-Fish-Stock-1995.

32 Latuconsina.
} 
fish stocks in the Central and Western Pacific Ocean under UNCLOS 1982 and UNIA 1995.

The West and Central Pacific Ocean Fisheries Commission (WCPFC) was established in Honolulu, the United States, on September 4, 2000, active on June 19, 2004. Members: Australia, China, Cook Islands, Federated States of Micronesia, Fiji Islands, South Korea, Kiribati, Marshall Islands, Nauru, New Zealand, Niue, PNG, Samo, Solomon Islands, Tonga, Tuvalu, Philippines, and European Union. Those who are Cooperating NonMembers are Taiwan and Indonesia fisheries organizations. Indonesia has been a nonmember of cooperation since 2004. ${ }^{33}$ In 2013 Indonesia became a member through Presidential Regulation No. 61 of 2013 concerning Ratification of the WCPFC Convention. ${ }^{34}$

Indonesia is a full member of the three RFMOs, which is an implementation of Law No.31 of 2004 Article 10 (2), which mandates the Indonesian government to actively participate in the membership of regional and international agencies/institutions/ organizations in the framework of cooperation in fisheries management. As a follow-up, it was then issued the Regulation of the Minister of Marine and Fisheries of the Republic of Indonesia No. PER.12/MEN/2012 concerning Capture Sea Fishing Business. In his consideration, it was stated "that Indonesia has the right to access and opportunity to take advantage of the potential of far-reaching fish stocks and limited supply of fish in the open sea.

Any fishing vessel or fish carrier operating on the high seas can land their catches in Indonesia or in other countries that are members of the RFMO in the same RFMO region. ${ }^{35}$ Fishing vessels can carry out transshipment on the high seas or in ports in other countries that are members of the RFMO in the same RFMO area. ${ }^{36}$

Every fishing vessel or carrier on the high seas must comply with the requirements and/or international standards set by RFMO, if it is not considered to carry out IUU Fishing activities, and is included in the IUU Vessel List with classification 1) Draft IUU Vessel List, 2) Provisional IUU Vessel List; and 3) IUU Vessel List. ${ }^{37}$

Every person whose ship is listed in the IUU Vessels List classification must support by providing accurate and timely data and information in the context of removing fishing vessels or fishing vessels from the IUU Vessels List classification. ${ }^{38}$ Fishing vessels or fish carriers registered in the RFMO vessel list can be removed, if they are suspected of carrying out IUU Fishing.

Consequently, from the issuance of this Ministerial Regulation, Indonesia has an obligation to carry out fisheries monitoring on board, to meet the higher quality data needs. So that Indonesia is faced with carrying out monitoring on fishing vessels operating in the convention area of the RFMOs, namely the Indian Ocean Tuna Commission, the

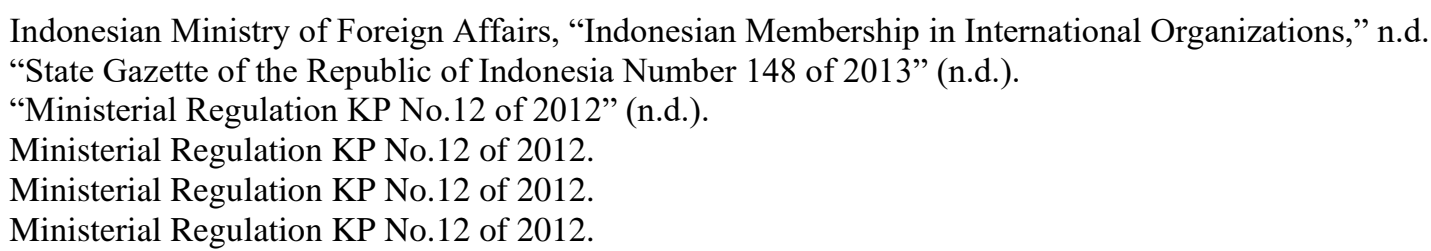


Commission for Southern Blue Fin Tuna Conservation, and the Central and Western Pacific Fisheries Commission.

\section{CONCLUSION}

Based on the description above, it can be concluded that Indonesia has implemented the provisions of the 1982 UNCLOS in the form of the utilization of far-tailed fish in two forms. The first implementation, in the form of legislation, Indonesia, which until now has issued around 17 regulations, from the level of the Law to the Ministerial Regulation. The second form of implementation is the activity as a member of a regional fisheries organization whose territory borders on the Indonesian EEZ. The three organizations are the Indian Ocean Tuna Commission, the Commission for Southern Bluefin Tuna Conservation, and the Central and Western Pacific Fisheries Commission.

In order to create responsible and sustainable fisheries management and follow up on the implementation carried out by Indonesia, namely immediately formulate fisheries policies in the high seas outside the Indonesian EEZ which involve and benefit Indonesian fishermen and preparing the apparatus and facilities and infrastructure that can support the compliance and enforcement of laws and regulations that have been issued by Indonesia.

\section{REFERENCES}

Affairs, Indonesian Ministry of Foreign. "Indonesian Membership in International Organizations," n.d.

Dwiponggo, A. "Pemanfaatan Dan Pengelolaan Optimal Perikanan Laut Dalam Pembangunan Jangka Panjang (PJP) Tahap II." In Prosiding Forum-II Perikanan, 114. Jakarta: Balitbang Pertanian Pusat Penelitian dan Pengembangan Perikanan kerjasama dengan USAID/FRDF, 1991.

FAO. “About IPOA-IUU.” Accessed May 17, 2016. http://www.fao.org/fishery/ipoaiuu/about/en.

FAO Code Conduct for Responsible Fisheries (CCRF) 1995 (n.d.).

FAO Compliance Agreement 1993 (n.d.).

Antara News. "Indonesia Is More Active in Managing Tuna Fisheries in the Indian Ocean," n.d.

Kasijan Romimohtarto. "Pengelolaan Pemanfaatan Kekayaan Hayati Dan Nabati Di Perairan Indonesia.” Seminar Hukum Nasional Kelima Tahun 1990. Jakarta, 1991.

Latuconsina, Husain. "Fisheries Development Opportunities and Challenges through UN Fish Stock 1995." Accessed May 5, 2013. https://id.scribd.com/document/ 22593051/Peluang-Dan-Tantangan-Pembangunan-Perikanan- Me-lalui-Un-Fish-Stock1995.

Law No. 45 of 2009 Amending Law No. 31 of 2004 concerning Fishery (n.d.).

Minister of Maritime Affairs and Fisheries Regulation Number PER.12/MEN/2012 concerning Capture Fisheries Business in The Sea (n.d.).

Ministerial Regulation KP No.12 of 2012 (n.d.).

"Non-Formal Cooperation Members." Accessed April 18, 2017. 
http://www.ccsbt.org/site/origins_of_the_convention.php.

Noviani, Ana. "Indonesia Registers 1,256 Fishing Vessels in the IOTC." Accessed April 28, 2017. http://industri.bisnis.com/read/ 20131222/99/193752/indonesia- 1,256-boat-fishdi-iotc.

Nurhidayatuloh, and Febrian. "ASEAN and European Human Rights Mechanisms, What Should Be Improved?” Padjadjaran Journal of Law 6, no. 1 (2019): 151-67.

Rahmantya, Krisna Fery, Anggie Destiti Asianto, and Dadang Wibowo. Analisis Data Pokok Kelautan Dan Perikanan 2015. Edited by Rennisca Ray Damanti and Mareta Nirmalanti. Jakarta: Pusat Data, Statistik dan Informasi Kementerian Kelautan dan Perikanan, 2015.

"Regional Fishery Bodies Summary Descriptions Indian Ocean Tuna Commission (IOTC)." Accessed May 17, 2013. http://www.fao.org/fishery/org/iotc_inst/en.

State Gazette of the Republic of Indonesia Number 148 of 2013 (n.d.).

The United Nations. The United Nations Convention on the Law of the Sea (1982).

United Nations Implementing Agreement 1995 (UNIA) (n.d.).

Wang Yanfang. "Top 10 Fastest Fish in the World." Accessed April 27, 2017. http://www.china.org.cn/top10/2010-12/28/content_21633018_5.htm. 